\title{
Synthesis of Tetrapeptide Derived from Skin Structural Protein Sequence and Identification of Skin Anti-aging Effect
}

\author{
Sang Moon Kang ${ }^{1,+, *}$, Yong-Seung Joun ${ }^{1, * *}$, Kee-Young Lee ${ }^{1, * *}$, Hyun Kang ${ }^{2, * * *}$ \\ and Sung-Gyu Lee Le*** $^{2, *}$ \\ ${ }^{1}$ R\&D Center, ANPEP Inc., Cheongju-si, Chungcheongbuk-do 28101, Korea \\ ${ }^{2}$ Department of Medical Laboratory Science, College of Health Science, \\ Dankook University, Cheonan-si, Chungnam 31116, Korea
}

\begin{abstract}
Several structural proteins present in keratinocytes of the skin are known to play an important role in the formation of epidermal tissue and barrier function, and the absence of structural proteins in keratinocytes causes various skin diseases. In this study, 42 types of tetrapeptides derived from the sequence of Loricrin, a kind of terminally differentiating structural protein, were synthesized, and skin anti-aging properties were measured by measuring the elastase inhibition, proliferation of skin cells. The anti-aging efficacy was verified and, based on this, it succeeded in selecting one of the most excellent peptides. It is expected that the selected tetrapeptide can be used as a raw material for various cosmetics and quasi-drugs based on anti-aging and skin cell proliferation effects.
\end{abstract}

Key Words: Loricrin, Tetrapeptide, Peptide synthesis, Anti-oxidant, Cell proliferation

\section{서 론}

피부는 인체에서 가장 큰 조직으로 햇빛이나 물리, 화 학적 자극으로부터 신체 내부를 보호해 주는 기능을 하 며 이는 인간의 생명 유지를 위해 절대적으로 필요하며 끊임없이 재생되어 항상성을 유지시킨다. 피부는 바깥쪽 으로부터 표피, 진피, 피하지방 순서대로 구성되어 있으 며 가장 얇은 조직인 표피는 피부의 보습과 보호를 담당 하는 중요한 기능을 담당하고 있으며 수분 손실, 손상과 세균 침입 등을 방지하는 역할을 맡고 있다. 피부는 신체 를 전부 감싸고 있는 조직으로 다양한 기능을 가지고 있 다. 신체 내부와 외부 사이에서 장벽 기능을 가지고 있으 므로 랑게르한스섬에 의한 면역 체계를 갖추고 있고 표
피에 의한 수분 조절 기능을 가지고 있음. 또한, 적절한 햇빛으로 비타민 $\mathrm{D}$ 를 합성하고 지질의 저장고와 땀샘으 로의 배설 기능도 수행한다. 건강한 피부에서의 정상적인 분화과정에 의해 생성된 각질층은 피부의 보습을 유지하 고 외부 환경의 자극으로부터 보호하는 기능을 가지고 있다. 이러한 기능을 피부 장벽 기능이라 하며 표피의 가 장 중요한 역할이라고 할 수 있다.

각질층은 외부 환경으로부터 우리 몸을 보호하고 우리 신체 내의 체액이 외부로 소실되는 것을 막는 최 전방의 방어막으로서의 기능을 수행한다. 각질형성세포(keratinocytes)가 분화하는 동안 그 세포막은 '각질세포막(cornified envelope)'이라는 독특한 구조물로 대체된다. 각질세포막 에는 여러 불용성 단백질들이 교차 결합(cross-link)하여 구조체를 형성하며, 세포 외부의 지질막에 둘러싸인 상태

Received: November 8, 2021 / Revised: December 8, 2021 / Accepted: December 10, 2021

${ }^{*}$ Research director, ${ }^{* *}$ Principal researcher, ${ }^{* * *}$ Professor.

${ }^{\dagger}$ Corresponding author: Sang Moon Kang. R\&D Center, ANPEP Inc., 13 Oksansandan 1-ro, Oksan-myeon, Heungdeok-gu, Cheongju-si, Chungcheongbuk-do 28101, Korea

Tel: +82-43-241-3360, Fax:+82-43-241-3365, e-mail: smkang@anpep.com

(C) The Korean Society for Biomedical Laboratory Sciences. All rights reserved.

(c) This is an Open Access article distributed under the terms of the Creative Commons Attribution Non-Commercial License (http://creativecommons.org/licenses/by-nc/3.0/) which permits unrestricted non-commercial use, distribution, and reproduction in any medium, provided the original work is properly cited. 
에서 지질막을 구성하는 일부 지질성분과 공유 결합을 이루어 물리적인 장벽을 형성하여 외부의 위협으로부터 인체를 보호할 수 있게 한다. 특히 각질 조직 내 존재하 는 다양한 구조 단백질(Structural protein) 표피 조직의 형 성과 장벽 기능에 중요한 역할을 하는 것으로 알려져 있 으며 각질세포 내 구조 단백질의 부재로 인해 야기되는 다양한 피부 질환이 존재한다(Cho et al., 2005; Hwang et al., 2011).

Loricrin은 terminally differentiating structural protein의 일 종으로 각화(cornified)된 피부 외벽의 $70 \%$ 를 차지하며 각 질층의 피부 보호 장벽 기능을 기여하는 것으로 알려져 있다. 생체 내에서 Loricrin은 포유류의 모든 층상 상피 (stratified epithelia)에서 발현되며 신생아 표피, 구강 및 항 문 점막의 상피, 식도, 포피, 질 및 땀샘의 표피 부분과 같은 습한 조직에서 가장 높은 수준으로 발현된다. 특히 Loricrin은 구강 점막하 섬유증(oral sub mucous fibrosis) 및 백색판증(leukoplakia) 같은 잠재적인 악성 장애의 초기 단 계에서 마커로서 활용되고 있다(Nithya et al., 2015).

펩타이드(peptide)는 2개 이상의 amino acid로 구성된 생 체 내 분자로서 단백질과 동일한 단위체(monomer)로 구 성되지만 단백질과 유사하거나 다른 방식으로 생체 내 대사작용에 관여하고 있으며 특히 단백질에 비해 생산이 나 변형, 이 자유롭고 열과 $\mathrm{pH}$ 등의 안정성이 우수하여 다양하게 활용되고 있는 물질이다(Bergmann and Zervas, 1932; McKay and Albertson, 1957; Carpino and Han, 1970; Chang and Meienhofer, 1978; Rich and Singh, 1979; Bayer and Rapp, 1986; Hojo et al., 2004). 특히 3차원 구조(3D structure) 가 중요한 단백질과 달리 서열 정보(sequence)에 의한 1 차 구조에 의해 성질이나 생리 활성이 좌우되어 다양한 물 질들과의 융합 및 혼합 등이 용이한 장점을 보인다. 또한 단백질의 활성 부위(active site)의 서열로 합성된 펩타이드 는 전체 단백질의 활성과 유사한 활성을 보이기도 한다. 이렇게 확보된 펩타이드는 단백질에 비해 쉽게 확보가 가능하고 보관, 활성 유지 등에서 유리하여 다양한 분야 에서 활용이 가능한 장점이 있다(Kim et al., 2011; Moh et al., 2011).

이러한 장점들로 펩타이드는 의약, 약학, 화장품 등 다 양한 분야에서 활용되고 있으며 또한 특정 서열의 펩타 이드에서 3차원 구조 모델링(3D structural modeling)을 통 해 좀더 효능과 안정성을 개선한 펩타이드를 설계하는 펩 티도미메틱(Peptidomimetic) 기술 등으로 고도화되고 있다.

일반적으로 펩타이드의 경제적 효용가치는 펩타이드
서열과 길이에 의해 좌우되는데 아미노산 서열에 따라 합성의 난이도와 효율에 차이가 발생하며 아미노산이 펩 타이드에 추가가 될 때마다 비용은 크게 증가되므로 의 약품용이나 화장품용 펩타이드의 서열은 일반적으로 3 6 아미노산에 집중되어 있으며 이보다 긴 서열은 경제성의 문제로 활성이 입증되더라도 적용이 힘든 경우가 다수 존재한다(Kunz and Birnbach, 1984; Kunz and Schaumlöffel, 1985; Lloyd-Williams et al., 1997; Hojo et al., 2001; Hojo et al., 2003).

본 연구에서는 피부 구조 단백질인 Loricrin의 서열을 바탕으로 42종의 펩타이드를 발굴, 합성한 후 다양한 활성 을 점검하여 해당 펩타이드의 활성과 독성을 확인하며 다 양한 피부 질환의 치료 및 피부 안티에이징 화장품의 원 료로서 활용 가능성을 검증하고자 한다(Tesser and BalvertBeers, 1975; Presland and Jurevic, 2002; Park et al., 2009; Park and Kim, 2010).

\section{재료 및 방법}

\section{실험 재료}

펩타이드 합성에 필요한 용매(Trifluoroacetic acid; TFA, Ethanol, methanol, hexane, chloroform, ethyl acetate, n-butane) 와 아미노산은 Sigma-Aldrich Co. (St. Louis, MO, USA)에 서 구매하여 사용하였으며 UV-visible spectrophotometer는 Varian (Belrose, Australia)사의 Cary 50, $\mathrm{pH}$ 미터는 Hanna (Seoul, Korea)사 제품을 사용하였으며, HPLC는 Shimadzu (Kyoto, Japan)사의 Shim-pack VP-ODS C18 column (250 mm $\times 4.6 \mathrm{~mm}, 5 \mu \mathrm{m})$ 제품을 사용하였으며, LC/ESI-MS/MS는 Applied Biosystems (Sanpracisco, USA) 제품을 사용하였다.

Dimethyl sulfoxide (DMSO)와 3-(4,5-Dimethylthiazol-2-yl)2,5-Diphenyltetrazol-ium Bromide (MTT), Elastase는 SigmaAldrich Chemical Co. (St. Louis, MO, USA)로부터 구입하 여 사용하였다. 세포 배양에 사용된 시약으로 fetal bovine serum (FBS), penicillin과 RPMI 1640 배지는 Gibco BRL Co. (Grand Island, NY, USA)에서 구입하여 사용하였다. 실험에 사용한 세포는 HDF (Human dermal fibroblast)는 neonatal (ATCC No. PCS-201-010)은 ATCC에서 구매하였으며 모유 두세포(Dermal Papilla; DP)는 Promocell GmbH (Heidelberg, Germany)사에서 인간 keratiocyte인 $\mathrm{HaCaT}$ 세포주는 한국 세포주은행(Seoul, Korea)에서 분양 받아 사용하였다. 


\section{펩타이드 라이브러리 확보}

서열을 통해 총 42 종의 펩타이드 서열을 도출하였으 며 해당 펩타이드의 서열은 Table 1에서 확인할 수 있다. Table 1의 펩타이드를 합성하기 위한 펩타이드 라이브러 리를 구축하기 위해 19 개의 nsc-아미노산(nsc-Ala, nsc-Arg (pbf), nsc-Asp (OtBu), nsc-Asn (trt), nsc-Gly, nsc-Glu (OtBu), nsc-Gln (trt), nsc-His (trt), nsc-Ser (tBu), nsc-Thr (tBu), nsc-Tyr (tBu), nsc-Trp (Boc), nsc-Leu, nsc-Ile, nsc-Val, nsc-Phe, nscMet, nsc-Lys (Boc), nsc-Pro)이 부착된 클로로 트리틸 클로 라이드 레진(Chloro trityl chloride resin: CTL resin, Novabiochem Cat No. 01-64-0021)을 96웰 테프론 반응기에 시 리즈 별로 각 19 라인에 $50 \mathrm{mg}$ 을 넣고 메틸렌 클로라이 드(MC) $1 \mathrm{~mL}$ 를 가하여 3 분간 교반하였다. 용액을 제거하 고 디메틸포름아마이드(DMF) $1 \mathrm{~mL}$ 를 넣어 3 분간 교반 한 후 다시 용매를 제거하였다. 제조된 트라넥삼산-펩티 딜 레진은 $\mathrm{DMF}, \mathrm{MC}$ 및 메탄올로 각각 3 번을 세척하고, 질소 공기를 천천히 흘려 건조한 후, $\mathrm{P} 2 \mathrm{O} 5$ 하에서 진공으 로 감압하여 완전히 건조하였다. 제조된 레진에 탈루용 액[트리플로로화 초산(Trifluroacetic acid; TFA) $81.5 \%$, 증
류수 5\%, 티오아니졸(Thioanisole) 5\%, 페놀 5\%, EDT (1,2Ethanedithiol) 2.5\% 및 TIS (Triisopropylsilane) 1\% 포함] $30 \mathrm{~mL}$ 을 넣은 후 상온에서 가끔 흔들어주며 얼음 수조 안에서 1 시간 반응을 유지하였다. 레진을 여과하고, 소량 의 TFA 용액으로 세척한 후 모액과 합하였다. 이 후 테 트라 펩타이드 서열 펩타이드를 수득하였다. 펩타이드 합 성에 대한 전체적인 모식도는 Fig. 1 에 나타내었다.

\section{펩타이드 분석}

합성된 42종의 펩타이드의 순도 및 분자량을 확인하기 위해 HPLC 분석을 진행하였다. 각 펩타이드를 waters사 의 HPLC (waters 2695)와 waters의 C18 (Waters Xterra MS C18 column (L: $250 \mathrm{~mm}, \mathrm{LD}: 4.6 \mathrm{~mm}, 5 \mu \mathrm{m})$ ) 컬럼을 이용하 여 분석하였다. 이때 $\mathrm{HPLC}$ 의 검출기의 파장은 $216 \mathrm{~nm}$ 파장을 이용하였다. HPLC의 이동상의 용매로는 $0.1 \%$ 삼 불소 아세트산(Trifluoroacetic acid, TFA)이 포함된 아세토 니트릴(Acetonitile, $\mathrm{ACN}$ )과 $0.1 \% \mathrm{TFA}$ 가 포함된 water를 이 용하였으며, 시간에 따라 $\mathrm{ACN}$ 의 농도를 변화시킴으로서 펩타이드의 순도 분석을 관찰하였다. 펩타이드 물질 분 석에 필요한 조건은 아래 Table2과 같다.

Table 1. Sequence of Tetrapeptide derived from Loricrin

\begin{tabular}{clc|ccc}
\hline \hline Number & Sequence & Molecular weight & Number & Sequence & Molecular weight \\
\hline 1 & MSYQ & 455.19443 & 22 & FSSG & 324.15394 \\
2 & QKKQ & 458.3071 & 23 & GQLE & 373.221047 \\
3 & PTPQ & 369.2118 & 24 & ELPE & 414.236377 \\
4 & PPVD & 354.20081 & 25 & EQQE & 460.20236 \\
5 & DCVK & 391.19943 & 26 & LELP & 398.292184 \\
6 & VKTS & 361.2431 & 27 & GQLK & 372.273417 \\
7 & KTSG & 319.19614 & 28 & KHLE & 453.294887 \\
8 & SGGS & 234.10698 & 29 & EHQE & 469.20269 \\
9 & GSGY & 310.13828 & 30 & EGQL & 373.221047 \\
10 & GQVS & 317.18049 & 31 & LEVP & 384.262197 \\
11 & GYVS & 352.18524 & 32 & PEEQ & 429.19655 \\
12 & SQQV & 388.21761 & 33 & QMGQ & 390.17911 \\
13 & TQTS & 363.18597 & 34 & GQDP & 343.15966 \\
14 & CAPQ & 345.15766 & 35 & QLKY & 478.315287 \\
15 & QPSY & 421.20671 & 36 & YLEQ & 479.262917 \\
16 & YGGG & 280.12771 & 37 & EQQE & 460.20236 \\
17 & SSGG & 234.10698 & 38 & TKGE & 361.20671 \\
18 & GGSG & 204.09641 & 39 & VLLP & 368.318004 \\
19 & GSSG & 234.10698 & 40 & VEHQ & 439.22851 \\
20 & GCFS & 340.1311 & 41 & QQKQ & 458.27071 \\
21 & GFSS & 370.14167 & 42 & EVQW & 488.24892 \\
\hline
\end{tabular}




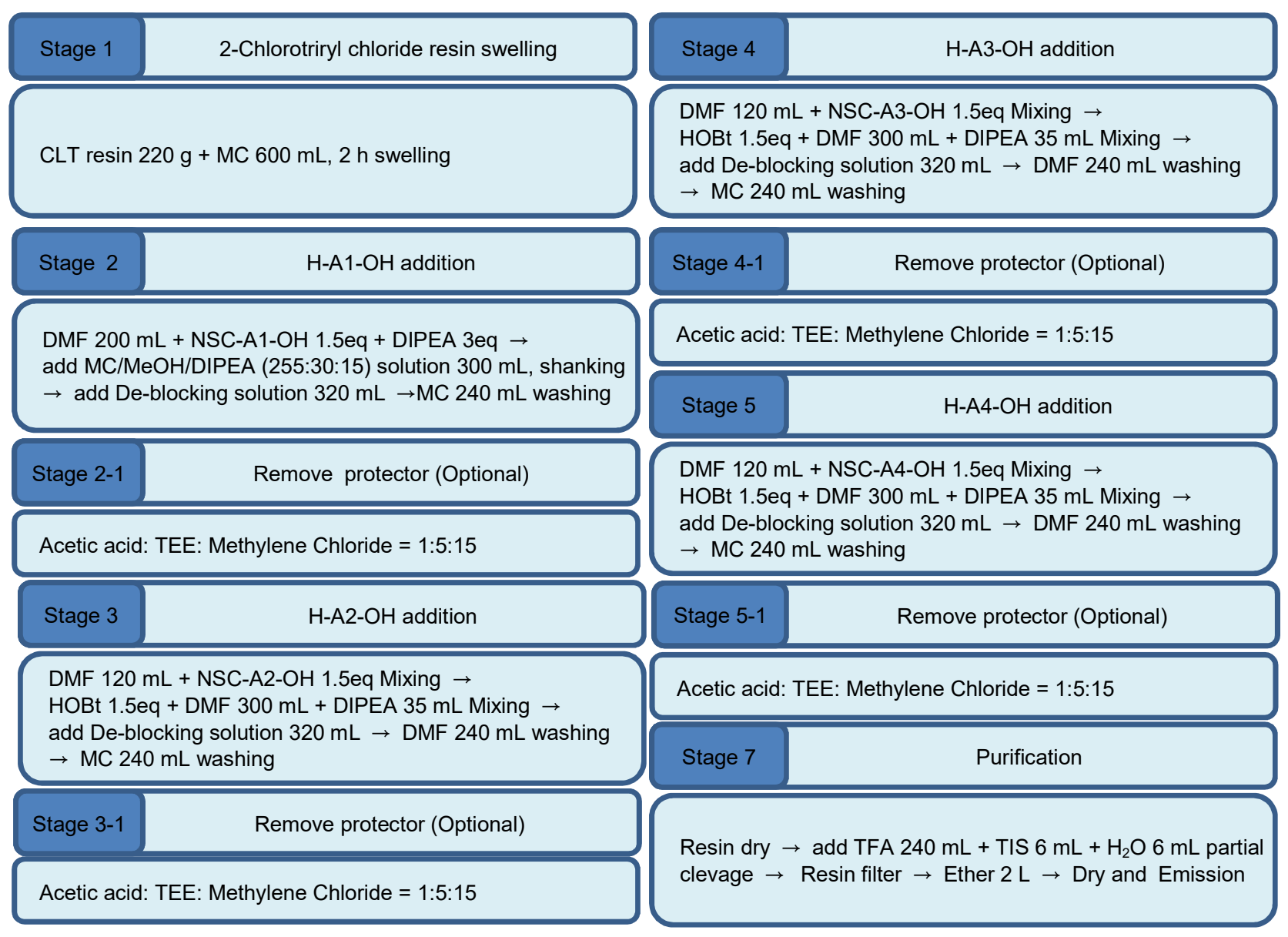

Fig. 1. Solid phase synthesis of tetrapeptides. The protecting groups for the amino groups used in the peptide synthesis are 2-(4Nitrophenyl) sulfonylethoxycarbonyl (Nsc); using N-terminal and t-butyloxycarbonyl (Boc); using R group.

Table 2. HPLC condition of Tetrapeptide derived from Loricrin

\begin{tabular}{|c|c|c|c|c|}
\hline \multicolumn{5}{|c|}{ Condition of HPLC analysis } \\
\hline Column & \multicolumn{4}{|c|}{ Shim-pack VP-ODS C18 column (L: 250 mm, LD: 4.6 mm, 5 нm) } \\
\hline Detector & \multicolumn{4}{|c|}{ UVD 170s DIONEX } \\
\hline Detection wavelength & \multicolumn{4}{|c|}{$216,254 \mathrm{~nm}$} \\
\hline Flow rate & \multicolumn{4}{|c|}{$1.0 \mathrm{~mL} / \mathrm{min}$} \\
\hline Injection volume & \multicolumn{4}{|c|}{$50 \mu \mathrm{L}$} \\
\hline \multirow{7}{*}{$\begin{array}{l}\text { Mobile phase conditions for } \\
\text { HPLC gradient-elution }\end{array}$} & $\begin{array}{c}\text { Program } \\
\text { order }\end{array}$ & $\begin{array}{l}\text { Time } \\
(\min )\end{array}$ & $\begin{array}{l}0.1 \% \mathrm{TFA}^{1)} \\
\text { in D.W }(\%)\end{array}$ & $\begin{array}{c}0.1 \% \mathrm{TFA}^{1)} \\
\text { in } 50 \% \mathrm{ACN}^{2)}(\%)\end{array}$ \\
\hline & 1 & 0 & 100 & 0 \\
\hline & 2 & 10 & 75 & 25 \\
\hline & 3 & 20 & 50 & 50 \\
\hline & 4 & 30 & 25 & 75 \\
\hline & 5 & 40 & 0 & 100 \\
\hline & 6 & 45 & 100 & 0 \\
\hline
\end{tabular}




\section{테트라 펩타이드의 Elastase 활성 억제 시험}

합성된 테트라 펩타이드 42 종의 피부 주름 개선 효과를 확인하기 위해 엘라스타제 억제 시험을 진행하였다. 기 질로서 N-succinyl-(L-Aal)3-p-nitroanilide를 사용하여 $37^{\circ} \mathrm{C}$ 에서 30 분간 p-nitroanilide의 생성량을 측정하였다. 각 시 험 펩타이드와 음성, 양성대조군을 $100 \mu \mathrm{g} / \mathrm{mL}$ 씩 시험관에 취하고 pancreatic solution (Type I: from porcine pancreas 유 래, 0.6 unit $/ \mathrm{mL}$, Sigma Aldrich, USA)용액 $50 \mu \mathrm{g} / \mathrm{mL}$ 을 가 한 후 기질로 $50 \mathrm{mM}$ Tris- $\mathrm{HCl}$ buffer $(\mathrm{pH}$ 8.6)에 녹인 Nsuccinyl-(LAla)3-p-nitroanilide $(1 \mathrm{mg} / \mathrm{mL})$ 을 $100 \mu \mathrm{g} / \mathrm{mL}$ 을 첨 가하여 30 분간 반응시키고 microplate reader를 이용하여 $410 \mathrm{~nm}$ 에서 흡광도를 측정하였다. Elastase 저해 활성은 시료용액의 첨가구와 무첨가구의 흡광도 감소율로 나타 내었다.

Elastase inhibition rate $(\%)=\frac{\begin{array}{c}\text { Absorbance of control - } \\ \text { absorbance of sample }\end{array}}{\text { Absorbance of contro1 }} \times 100$
42종의 합성 펩타이드를 처리한 뒤 엘라스타제 활성 억제 효과를 측정하였다.

\section{세포주 배양}

$\mathrm{DP}$ 세포와 $\mathrm{HaCaT}$ 세포는 Dulbecco's Modified Eagle Medium (DMEM; Gibco BRL, Gaithersberg, USA) 배지에 $10 \%$ FBS (Gibco BRL)와 1\% penicillin-streptomycin (Gibco $\mathrm{BRL})$ 을 첨가하여 기본 배지로 사용하였고, $37^{\circ} \mathrm{C}, 5 \% \mathrm{CO}_{2}$ 조건의 배양기에서 2 3일에 한 번씩 계대 배양 하였다.

\section{MTT assay}

$\mathrm{DP}$ 세포를 48 well-plate에 $1 \times 10^{4}$ 개로 분주하여 24 시간 배양하였다. 배양세포에 GQVS를 $0,25,50,100,200 \mu \mathrm{g} /$ $\mathrm{mL}$ 로 처리하여 72 시간 배양하였고, $\mathrm{HaCaT}$ 세포는 배양 후 48 well-plate에 $1 \times 10^{4}$ 개로 분주하여 24 시간 배양 후 배양세포에 GQVS를 $0,25,50,100,200 \mu \mathrm{g} / \mathrm{mL}$ 로 처리하 여 24시간 배양하였다. 각 세포주 별로 배양 후 $5 \mathrm{mg} /$ $\mathrm{mL}$ MTT (Sigma) 시약을 $10 \mu \mathrm{L}$ 가하고 4시간을 배양하였

Table 3. Result of Tetrapeptides derived from Loricrin

\begin{tabular}{cllll|llllc}
\hline \hline Number & Sequence & $\begin{array}{c}\text { Molecular } \\
\text { weight }\end{array}$ & $\begin{array}{c}\text { Purity } \\
(\%)\end{array}$ & $\begin{array}{c}\text { Yield } \\
(\%)\end{array}$ & Number & Sequence & $\begin{array}{c}\text { Molecular } \\
\text { weight }\end{array}$ & $\begin{array}{c}\text { Purity } \\
(\%)\end{array}$ & $\begin{array}{c}\text { Yield } \\
(\%)\end{array}$ \\
\hline 1 & MSYQ & 455.19443 & 92.54 & 32.51 & 22 & FSSG & 324.15394 & 97.25 & 29.21 \\
2 & QKKQ & 458.3071 & 95.21 & 30.25 & 23 & GQLE & 373.221047 & 95.12 & 30.54 \\
3 & PTPQ & 369.2118 & 93.21 & 29.21 & 24 & ELPE & 414.236377 & 93.21 & 27.14 \\
4 & PPVD & 354.20081 & 92.54 & 28.01 & 25 & EQQE & 460.20236 & 95.88 & 28.65 \\
5 & DCVK & 391.19943 & 98.21 & 27.98 & 26 & LELP & 398.292184 & 95.17 & 32.99 \\
6 & VKTS & 361.2431 & 97.22 & 31.07 & 27 & GQLK & 372.273417 & 94.36 & 30.17 \\
7 & KTSG & 319.19614 & 95.21 & 30.98 & 28 & KHLE & 453.294887 & 95.87 & 30.54 \\
8 & SGGS & 234.10698 & 94.20 & 28.14 & 29 & EHQE & 469.20269 & 94.06 & 31.01 \\
9 & GSGY & 310.13828 & 95.83 & 27.14 & 30 & EGQL & 373.221047 & 95.08 & 27.14 \\
10 & GQVS & 317.18049 & 96.24 & 29.66 & 31 & LEVP & 384.262197 & 95.37 & 29.69 \\
11 & GYVS & 352.18524 & 97.21 & 30.17 & 32 & PEEQ & 429.19655 & 96.33 & 27.09 \\
12 & SQQV & 388.21761 & 96.21 & 33.01 & 33 & QMGQ & 390.17911 & 95.22 & 26.39 \\
13 & TQTS & 363.18597 & 96.55 & 28.74 & 34 & GQDP & 343.15966 & 99.71 & 30.72 \\
14 & CAPQ & 345.15766 & 93.18 & 29.44 & 35 & QLKY & 478.315287 & 94.21 & 29.66 \\
15 & QPSY & 421.20671 & 95.68 & 28.09 & 36 & YLEQ & 479.262917 & 95.36 & 27.17 \\
16 & YGGG & 280.12771 & 97.21 & 29.36 & 37 & EQQE & 460.20236 & 96.21 & 22.01 \\
17 & SSGG & 234.10698 & 96.12 & 31.14 & 38 & TKGE & 361.20671 & 94.21 & 30.74 \\
18 & GGSG & 204.09641 & 97.25 & 29.47 & 39 & VLLP & 368.318004 & 96.21 & 17.14 \\
19 & GSSG & 234.10698 & 96.33 & 27.21 & 40 & VEHQ & 439.22851 & 97.01 & 29.71 \\
20 & GCFS & 340.1311 & 94.18 & 21.88 & 41 & QQKQ & 458.27071 & 95.36 & 30.54 \\
21 & CFSS & 370.14167 & 95.36 & 30.07 & 42 & EVQW & 488.24892 & 94.06 & 28.14 \\
\hline & & & & & & & & & \\
\end{tabular}


다. 그 후 상층액을 제거하고 형성된 formazan을 DMSO $100 \mu \mathrm{L}$ 로 녹여 ELISA reader로 $550 \mathrm{~nm}$ 에서 흡광도를 측정 하였다.

\section{통계학적 분석}

대조군과 펩타이드 처리군 결과에 대한 통계처리는 Student's $t$-test로 비교하였으며, 통계처리 후 $P$ 값이 0.05 미만일 경우 통계적인 유의성이 있다고 판정하였다.

\section{결과 및 고찰}

\section{펩타이드 라이브러리 합성 및 HPLC 분석}

고체상 합성(solid phase synthesis)를 통해 확보된 42종의

A
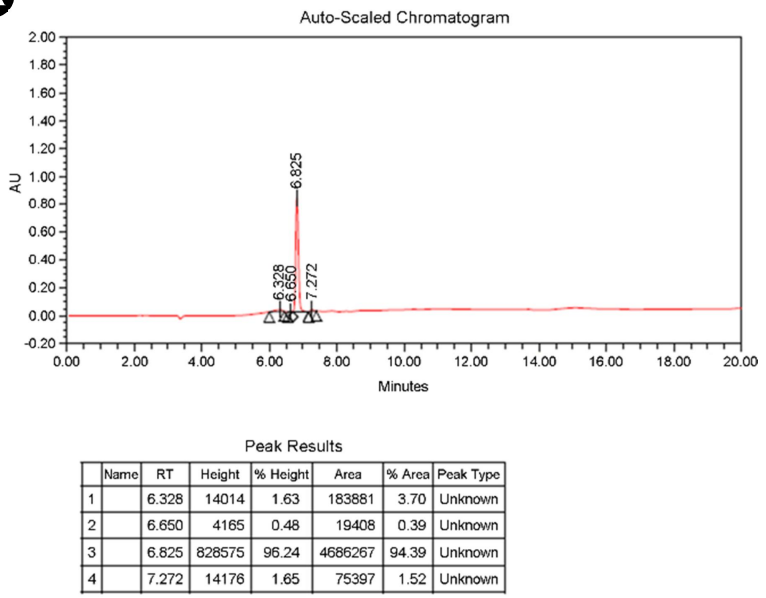

B

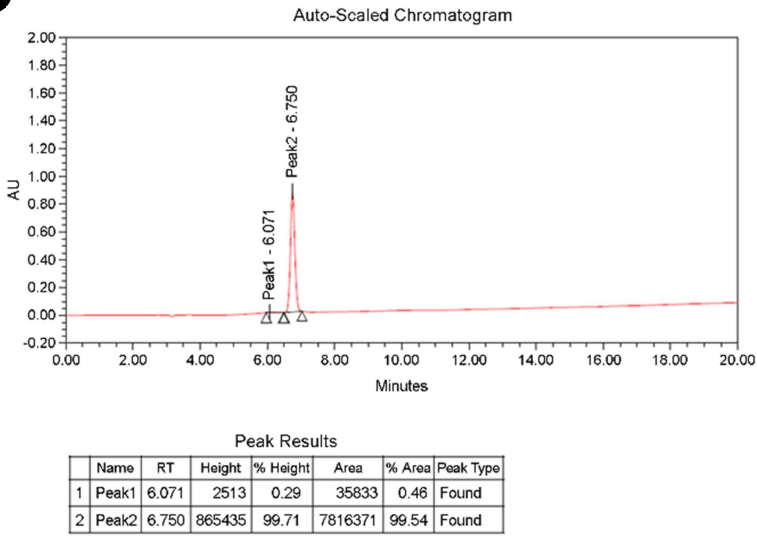

Fig. 2. HPLC analysis of Tetrapeptide. (A) Tetrapeptide No. 10, Sequence; GQVS, (B) Tetrapeptide No. 34, Sequence; GQDP, Peptides were identified by HPLC. HPLC Simadzu (Japan) Shim-pack VP-ODS C18 column $(250 \mathrm{~mm} * 4.6 \mathrm{~mm}, 5 \mu \mathrm{m})$
테트라 펩타이드의 합성 결과는 Table 3에 표기하였다. 합 성된 테트라 펩타이드의 수율은 펩타이드의 서열에 차이 에 따른 물성 차에 의해 상이하나 대략 $20 \%$ 대의 평균 수율을 보이고 있다. 합성된 펩타이드는 HPLC 분석을 통 해 순도를 확인하였으며 컬럼 분리 시 elution 시간도 역 시 상이하나 5 7분대에서 피크를 확인할 수 있었다. Fig. 2 와 같이 $90 \%$ 이상의 순도를 가진 테트라 펩타이드로 확 보되었다. 펩타이드 중 일부의 HPLC 분석 차트를 Fig. 3 에 표기하였다.

\section{엘라스타제 활성 억제 효과}

테트라 펩타이드의 피부 활성을 확인하기 위해 엘라스 타제 활성 억제 시험을 진행하였다. 엘라스타제(Elastase) 는 피부 진피 세포 내 콜라겐(collagen), 엘라스틴(elastin) 을 분해하는 효소로 피부세포의 증식 등에 필요한 효소 이나 과량 발현하면 진피 층 내 구조 단백질을 감소시켜 피부 주름의 원인이 되는 효소이다. 따라서 엘라스타제의 활성의 억제를 통해 피부의 주름을 억제할 수 있으며 많 은 피부 노화 방지 물질들의 경우 엘라스타제 활성 억제

\section{A}

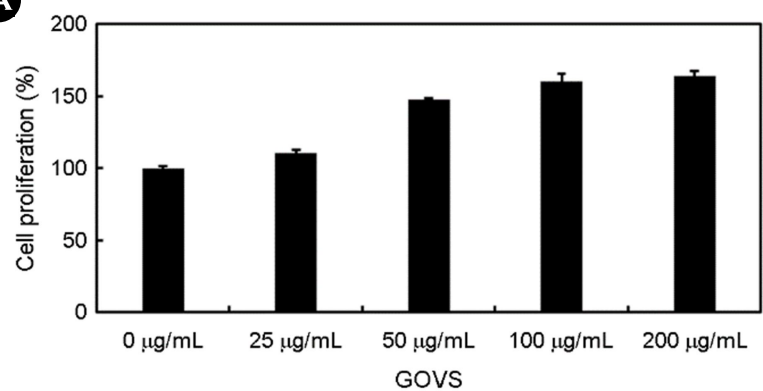

B

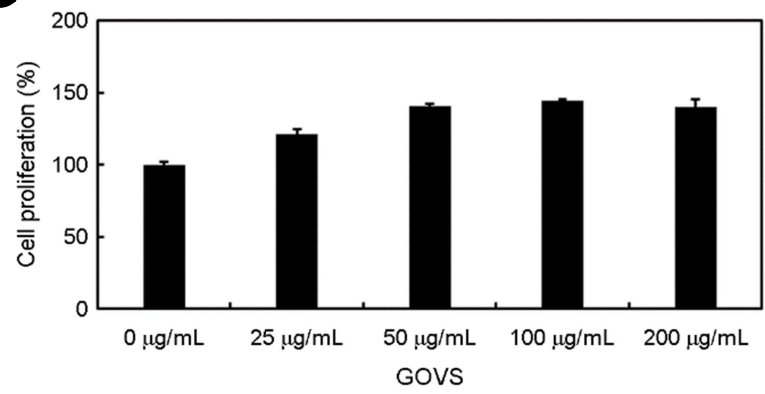

Fig. 3. The Effect of GQVS on the cell proliferation in DP and HaCaT cells. DP (A) and $\mathrm{HaCaT}$ cells (B) were treated with GQVS $(25,50,100$, and $200 \mu \mathrm{g} / \mathrm{mL})$ for $72 \mathrm{~h}$ and $24 \mathrm{~h}$, respectively. The proportion of survival cells was measured by MTT assay. Experiments were repeated in triplicate and the results were expressed as the mean $\pm \mathrm{SD}$. 
Table 4. Result of Elastase inhibition efficacy of Tetrapeptides

\begin{tabular}{|c|c|c|c|c|c|}
\hline Number & Sequence & Elastase inhibition (\%) & Number & Sequence & Elastase inhibition (\%) \\
\hline 1 & MSYQ & $79.4 \pm 5.6$ & 22 & FSSG & $69.1 \pm 4.4$ \\
\hline 2 & QKKQ & $88.7 \pm 6.3$ & 23 & GQLE & $73.2 \pm 3.3$ \\
\hline 3 & PTPQ & $69.3 \pm 4.9$ & 24 & ELPE & $90.5 \pm 4.2$ \\
\hline 4 & PPVD & $72.5 \pm 5.3$ & 25 & EQQE & $53.6 \pm 4.9$ \\
\hline 5 & DCVK & $118.4 \pm 3.3$ & 26 & LELP & $78.2 \pm 3.3$ \\
\hline 6 & VKTS & $66.3 \pm 4.8$ & 27 & GQLK & $56.0 \pm 5.2$ \\
\hline 7 & KTSG & $44.5 \pm 6.2$ & 28 & KHLE & $79.3 \pm 6.4$ \\
\hline 8 & SGGS & $49.6 \pm 5.8$ & 29 & EHQE & $66.3 \pm 6.3$ \\
\hline 9 & GSGY & $56.3 \pm 3.3$ & 30 & EGQL & $69.7 \pm 4.9$ \\
\hline 10 & GQVS & $33.9 \pm 5.4$ & 31 & LEVP & $70.6 \pm 5.5$ \\
\hline 11 & GYVS & $78.5 \pm 5.5$ & 32 & PEEQ & $64.0 \pm 6.4$ \\
\hline 12 & SQQV & $49.3 \pm 4.6$ & 33 & QMGQ & $55.6 \pm 5.7$ \\
\hline 13 & TQTS & $59.0 \pm 5.0$ & 34 & GQDP & $34.5 \pm 5.1$ \\
\hline 14 & CAPQ & $77.2 \pm 4.6$ & 35 & QLKY & $60.5 \pm 5.2$ \\
\hline 15 & QPSY & $63.5 \pm 5.3$ & 36 & YLEQ & $72.3 \pm 3.9$ \\
\hline 16 & YGGG & $67.1 \pm 4.4$ & 37 & EQQE & $64.2 \pm 4.0$ \\
\hline 17 & SSGG & $77.0 \pm 6.2$ & 38 & TKGE & $59.3 \pm 4.2$ \\
\hline 18 & GGSG & $103.5 \pm 3.2$ & 39 & VLLP & $60.7 \pm 5.3$ \\
\hline 19 & GSSG & $58.3 \pm 5.1$ & 40 & VEHQ & $55.7 \pm 4.9$ \\
\hline 20 & GCFS & $55.2 \pm 5.6$ & 41 & QQKQ & $72.3 \pm 5.4$ \\
\hline 21 & CFSS & $\mathbf{4 7 . 4} \pm 4.4$ & 42 & EVQW & $49.5 \pm 4.8$ \\
\hline - Control & - & $100 \pm 5.2$ & $\begin{array}{c}+ \text { Control } \\
\text { (Ursonic acid) }\end{array}$ & - & $28.8 \pm 3.6$ \\
\hline
\end{tabular}

능을 보이고 있다. 본 실험에서 합성된 테트라 펩타이드 의 경우 42 종의 펩타이드 중 일부의 펩타이드에서 또한 엘라스타제 저해능(\%)이 우수한 합성 테트라 펩타이드가 확인되었으며(Table 4)의 경우는 기존의 엘라스타제 억제 기능성 소재인 Ursonic acid에 비해서도 유사한 것으로 파악되었다 이러한 결과로부터 피부에 주름 생성을 유발 시키는 요인이 적용되었을 때 합성된 테트라 펩타이드가 엘라스타제 억제 효과를 통해 주름 생성을 억제해 피부 노화 방지에 효과가 있을 것으로 사료된다. Table 4는 테 트라 펩타이드의 구체적인 엘라스타제 활성 저해 스크리 닝 결과를 나타내었다.

\section{피부세포 증식 촉진 효과}

앞선 엘라스타제 활성 저해 실험을 통해 가장 우수한 결과를 보였던 tetrapeptide No. $10, \mathrm{GQVS}$ 가 DP 및 $\mathrm{HaCaT}$ 세포의 증식에 미치는 영향을 확인하기 위하여 시료를 농도 별 $(25,50,100,200 \mu \mathrm{g} / \mathrm{mL})$ 로 처리하고 각각 72 시간
과 24시간 후 MTT assay를 이용하여 측정하였다. 실험 결 과, $\mathrm{DP}$ 세포의 경우 각각의 농도에서 72 시간 후 대조군 $(100 \%)$ 에 비해 $110.23( \pm 2.21) \%, 147.37( \pm 1.24) \%, 160.23$ $( \pm 5.21) \%, 164.21( \pm 3.24) \%$ 였으며, $\mathrm{HaCaT}$ 세포의 경우 24 시간 후 $121.14( \pm 3.11) \%, 140.70( \pm 1.57) \%, 144.32( \pm 1.27) \%$, $140.15( \pm 5.07) \%$ 로 나타났다. 본 결과를 통해 Tetrapeptide $\mathrm{GQVS}$ 는 농도의존적으로 2종의 세포, $\mathrm{DP}, \mathrm{HaCaT}$ 세포의 증식을 촉진하는 것으로 확인되었다.

본 연구를 통해 연구진은 구조 단백질의 일종인 Loricirn 의 서열에서 도출된 42 종의 tetrapeptide의 합성에 성공하 여 라이브러리를 완료하였으며 이들 tetrapepide의 엘라스 타제 억제능, 피부세포 증식 촉진 효능을 확인하였다. 결 과적으로 확보된 $\mathrm{GQVS}$ 서열의 tetrapepide는 $\mathrm{DP}$ 세포 증 식과 $\mathrm{HaCaT}$ 세포 증식의 촉진은 각각 모발의 성장과 피 부 주름 개선에 영향을 미칠 것으로 판단되며, 탈모 및 주름 개선 소재 개발의 기초자료가 될 것으로 사료된다. 


\section{ACKNOWLEDGEMENT}

This research was supported by the Ministry of Trade, Industry \& Energy (MOTIE), Korea Evaluation Institute of Industrial Technology (KEIT) through the Encouragement Program for Bio industry core technology development project (Project NO: 20009105).

\section{CONFLICT OF INTEREST}

No potential conflict of interest relevant to this article was reported.

\section{REFERENCES}

Bayer E, Rapp W. "Chemistry of peptides and Proteins" de Gryyter, Berlin, 1986. 3-8.

Bergmann M, Zervas L. Über ein allgemeines Verfahren der PeptidSynthese. Berichte der deutschen chemischen Gesellschaft (A and B Series). 1932. 65: 1192-1201.

Carpino LA, Han GY. J. 9-Fluorenylmethoxycarbonyl function, a new base-sensitive amino-protecting group. Am Chem Soc. 1970. 92: 5748-5749.

Chang CD, Meienhofer J. Solid-phase peptide synthesis using mild base cleavage of $\mathrm{N} \alpha$-fluorenylmethyloxycarbonylamino acids, exemplified by a synthesis of dihydrosomatostatin. Int J Pept Protein Res. 1978. 11: 246-249.

Cho YH, Kim JH, Lee DH, Lee BC, Pyo HB. Effect of etyl acetate fraction from melothria heterophylla on antioxidant activity and metrix metalloproteinase-1 expression in ultraviolet-A irradiated human dermal fibroblast. J Soc Cosmet Sci Kor. 2005. 31: 103-109.

Hojo K, Maeda M, Kawasaki KJ. A new water-soluble N-protecting group, 2-[phenyl(methyl)sulfonio]ethyloxycarbonyl tetrafluoroborate, and its application to solid phase peptide synthesis in water. Pept Sci. 2001. 7: 615-618.

Hojo K, Maeda M, Smith TJ, Kita E, Yamaguchi F, Yamamoto S, Kawasaki K. Chemical and pharmaceutical bulletin. 2004. 52: 422-427.

Hojo K, Maeda M, Takahara Y, Yamamoto S, Kawasaki K. A new reagent, 2-[phenyl(methyl)sulfonio]ethyl-4-nitro-phenylcarbonate tetrafluoroborate (Pms-ONp), for preparing watersoluble N-protected amino acids. Tetrahedron Lett. 2003. 44: 2849-2851.

Hwang JG, Yun JK, Han KH, et al. Anti-oxidation and anti-aging effect of mixed extract from Korean medicinal herbs. J Kor
Herbol. 2011. 26: 111-117.

Kim JK, Lee JH, Bae IH, Seo DB, Lee SJ. Beneficial effect of a collagen peptide supplement on the epidermal skin barrier. Kor J Food Sci Technol. 2011. 43: 458-463.

Kunz H, Birnbach S. Peptidsynthesen mit der hydrophilen, säureund basenstabilen 2-(4-Pyridyl)ethoxycarbonyl-Schutzgruppe. Tetrahedron Lett. 1984. 25: 3567-3570.

Kunz H, Schaumlöffel G. Die 2-(Triphenylphosphonio)isopropyloxycarbonyl-(Ppoc)-Gruppe und am Phosphonium-zentrum modifizierte analoge Reste als Aminoschutzgruppen bei der Peptidsynthese. Liebigs Ann Chem. 1985. 1784-1793.

Lloyd-Williams P, Albericio F, Giralt E. Chemical Approaches to the Synthesis of peptides and Proteins. CRC Press: Boca Raton and New York, 1997.

McKay FC, Albertson NF. New amine-masking groups for peptide synthesis. Journal of the American Chemical Society. 1957. 79 4686-4690

Moh SH, Jung DH, Kim HS, Cho MJ, Seo HH, Kim SJ. Characteristics and applications of bioactive peptides in skin care. Kor Soc Biotechnol Bioeng Jor. 2011. 26: 483-490.

Nithya S, Radhika T, Jeddy N. Loricrin - an overview. J Oral Maxillofac Pathol. 2015. 19: 64-68.

Park JM, Kim KJ. The anti-wrinkle effects and whitening effects of Galla Rhois. J Kor Ori Med Opht Otol. 2010. 23: 135-148.

Park YH, Kim JH, Choi JH, Park SY. Effects of eriobotryae folium as anti-oxidant on HaCaT keratinocyte. J Kor Orie Med Opht Otol Derm. 2009. 22: 20-35.

Presland RB, Jurevic RJ. Making sense of the epithelial barrier: What molecular biology and genetics tell us about the functions of oral mucosal and epidermal tissues. J Dent Educ. 2002. 66: 564-574.

Rich DH, Singh J. The carbodiimide method. In: Gross E, Meienhofer J, editors. The Peptides. Vol. 1. Academic Press; New York: 1979. 241-314.

Tesser GI, Balvert-Beers IC. The methylsulfonylethyloxycarbonyl group, a new and versatile amino protective function. Int $\mathrm{J}$ Peptide Protein Res. 1975. 7: 295-305.

https://doi.org/10.15616/BSL.2021.27.4.231

Cite this article as: Kang SM, Joun YS, Lee KY, Kang H, Lee SG. Synthesis of Tetrapeptide Derived from Skin Structural Protein Sequence and Identification of Skin Anti-aging Effect. Biomedical Science Letters. 2021. 27: 231-238. 